\title{
Nauczyciel w warunkach zmian społecznych - misja, służba czy zawód na rynku pracy?
}

\section{Wprowadzenie - jakie czasy, taki nauczyciel?}

Wpisywanie nauczycieli w rozmaite konteksty, przypisywanie im różnych ról i wyznaczanie zadań społecznych, znane jest od wieków. Wiele przykładów podaje m.in. historia myśli pedagogicznej. Rozważania w tym zakresie osadzić można na osi czasu: starożytność - współczesność. Starożytność, to przede wszystkim Sokrates, Arystoteles i Platon, których poglądy pedagogiczne i społeczne do dziś są aktualne. Sokrates, był nie tylko wspaniałym nauczycielem i obecnie uznawanym za wzorzec nauczycielski, ale także osobą zabierającą głos w sprawach publicznych. Znany jest porządek społeczny ustanowiony przez Platona. Swój ustrój idealnego państwa oparł na trzech stanach społecznych: rządcach, strażnikach i żywicielach. Z kolei Arystoteles zabierając głos w sprawach państwowych pisał w Polityce: „Państwo jest wówczas cnotliwe, jeśli wszyscy obywatele uczestniczący w jego rządach są cnotliwi, według mnie zaś wszyscy obywatele w zarządzie państwa uczestniczą"1. Dalej Arystoteles postuluje, aby „obywatele winni być tak wychowywani, by zdobyli przygotowanie do

$1 \quad$ Cyt. za S. Wołoszyn, Źródła do dziejów wychowania i myśli pedagogicznej, wyd. 2, Dom Wydawniczy Strzelec, Kielce 1995, s. 59. 
swoich zadań, by umieli za młodu słuchać, a w starszym wieku rządzić"2. Najbardziej znany rzymski nauczyciel Marek Fabiusz Kwintylian w swoim pedagogicznym dziele Kształcenie mówcy ${ }^{3}$ wiele miejsca poświęcił obyczajowości i powinnościom nauczyciela. Podkreślił m.in. jego społeczną rolę w podnoszeniu poziomu wykształcenia wszystkich obywateli bez względu na status społeczny. Obywatel powołany do kierowania sprawami publicznymi i prywatnymi, który mógłby rozważnie rządzić państwem, zasadzać je na prawach, wyzwalać z błędów wyrokiem sądowym, musi być człowiekiem moralnie dobrym ${ }^{4}$. Wieki mijały, a koncepcje pracy nauczyciela i jego role niewiele się zmieniały. Bogaty dwudziestowieczny dorobek pedagogiczny pozwala odwołać się m.in. do poglądów Johna Deweya i jego koncepcji szkoły stanowiącej miniaturę społeczeństwa. Aspektami jego edukacyjnej filozofii są: „1) edukacja jako przechowywanie i rekonstrukcja, 2) kształcenie a społeczeństwo, 3) społeczeństwo demokratyczne a edukacja, 4) nauczanie i uczenie się w ujęciu eksperymentalnym, 5) rozwój jako cel edukacji, 6) doświadczeniowy program nauczania, 7) rekonstruowanie doświadczenia a edukacja"5. Innymi słowy, John Dewey pojmował edukację jako rekonstrukcję i reorganizację doświadczenia, wzmacniającą jego znaczenie i powiększającą zdolność do kierowania jego biegiem. Wychowanie rozumiał jako przekaz doświadczenia życiowego, dzięki któremu zostaje utrzymana społeczna ciągłość życia ${ }^{6}$.

Nie można też pominąć działalności pedagogiczno-społecznej Marii Montessori, której poglądy społeczne zasadzały się na ścisłym związku człowieka z kulturą oraz cywilizacją i na postulatach o prawa kobiet i potrzebie reform społecznych. W polskim wymiarze wśród wielu znaczących pedagogów powołać się można na społeczne konteksty pedagogiki Jana Władysława Dawida, Anieli Szycówny, Stefanii Sempołowskiej czy Heleny Radlińskiej. Na szczególne podkreślenie zasługuje działalność pedagogiczno-społeczna Janusza Korczaka.

\footnotetext{
Ibidem, s. 60 .

M.F. Kwintylian, Kształcenie mówcy, przekł. M. Brożek, Wydawnictwo Ossolineum, Wrocław 1951.

$4 \quad$ S. Wołoszyn, Źródła do dziejów..., s. 107.

5 G.L. Gutek, Filozofia dla pedagogów, GWP, Gdańsk 2007, s. 97.

6 J. Dewey, Moje pedagogiczne credo, PWN, Warszawa 2005, s. 9-10.
} 
Druga połowa XX wieku zapisała się znanymi protestami środowisk nauczycielskich i akademickich przeciwko skostniałym systemom edukacyjnym, brakowi reform społecznych, niedemokratycznym podziałom społecznym, konserwatywnym normom społecznym, ograniczaniu wolności słowa i wolności osobistej. Uczestnicy wydarzeń 1968 roku postulowali głównie, by społeczeństwa zaczęły patrzeć w przyszłość, a nie zwracały się wciąż w kierunku przeszłości i powielały stare formy i schematy życia społecznego. Protesty, głównie nauczycieli, wykładowców oraz uczniów i studentów z 1968 roku, jak piszą znawcy tematu, przyczyniły się nie tylko do rewolucyjnych zmian w sferze społecznej czy edukacyjnej, ale również obyczajowej. W Polsce wystąpienia studentów i wykładowców nazywane są Marcem 1968. Niestety zostały one brutalnie spacyfikowane, a rządowa propaganda nazywała ich „wrogami ludu”. Nie można uznać jednak, że protesty te nie przyniosły żadnego skutku. Jak się wydaje, znacząco przyczyniły się do konsolidacji środowisk opozycyjnych oraz uświadomiły społeczeństwu, że można przeciwstawiać się apodyktycznej władzy.

O tym jak ważną rolę w społecznej świadomości odgrywają nauczyciele, można było się przekonać podczas strajku wiosną 2019 roku. Jeszcze żadna z protestujących grup zawodowych nie wzbudziła tak powszechnego zainteresowania. Nie było tak wielu komentarzy i opinii, skrajnie odmiennych na ten temat. Wśród wielu ocen tego wydarzenia można wyodrębnić trzy podstawowe nurty. W pierwszym, zawód nauczyciela traktowany być powinien jako misja. W związku z tym nauczyciele nie mają prawa do strajku. Powinni skupiać się tylko na nauczaniu i wychowywaniu swoich podopiecznych kosztem nawet swojego życia osobistego. Wykonywać ten zawód powinny tylko osoby o właściwych predyspozycjach i cechach osobowych. W związku z tym, że jest to zawód misyjny, nauczyciele nie powinni zabiegać o ekonomiczną stronę życia. Być kimś na kształt współczesnego „Doktora Judyma” czy „Siłaczki”. Natomiast nauczyciele niezadowoleni z warunków wykonywania zawodu powinni bezwzględnie z niego rezygnować. Nota bene $\mathrm{w}$ obecnym systemie edukacyjnym nie ma przestrzeni dla takich nauczycieli. Potrzebni są raczej tacy, którzy sprawnie będą funkcjonować w ramach określonych schematów i reguł.

Drugi nurt opinii społecznych był skoncentrowany na myśleniu, że zawód nauczyciela to służba. W związku z tym mają oni wykonywać swoje zadania określone w zawodzie i polecenia przełożonych oraz nie 
podejmować samodzielnych inicjatyw, zwłaszcza jeśli chodzi o protesty czy wyrażanie braku zaufania dla systemu. Nikt nie wspominał o tym, że tylko kreatywny i nowatorski nauczyciel będzie w stanie wychować uczniów na samodzielnie myślących, otwartych, potrafiących krytycznie postrzegać rzeczywistość i doceniających dziedzictwo kulturowe ludzi. W tym miejscu warto zasygnalizować kwestię, że angażowanie się nauczycieli w proces edukacyjny uczniów obecnie rozumiany być powinien jako oferta, propozycja, która jest przedłożona w sposób otwarty. Nauczanie nie może być utożsamiane z instruktażem i szkoleniem. Jurgen Habermas pisze, że preferowana jest postawa oświeconego mistrza, aktywnie oczekującego na oświecenie uczniów? ${ }^{7}$ W swoim dialogu pedagogicznym gość wspiera, mistrz wyjaśnia, partner modeluje postawy, zgodnie z potrzebami uczniów. Wśród metod dydaktyczno-wychowawczych istotne znaczenie powinny posiadać metody skupione na procesie uczenia się, w których ze strony nauczyciela uczący powinien spodziewać się wsparcia, zrozumienia i życzliwości. Taka rzeczywistość edukacyjna wymaga dużego potencjału metodycznego i komunikacyjnego oraz wrażliwości pedagogicznej. Nauczyciel pełniąc jedynie „służbę” nie będzie zdolny do takich zachowań pedagogicznych.

Trzeci nurt opinii społecznych potraktował zawód nauczyciela, jak każdy na rynku pracy. W wielu opiniach pojawiły się tezy, że zarówno wymagania, jak i prawa pracownicze nauczycieli winny być tożsame z innymi zawodami. Za efektywną pracę nauczyciele powinni być należycie opłacani, przynajmniej na poziomie specjalistów w gospodarce. Natomiast nauczyciele niepotrafiący podołać swoim obowiązkom powinni odejść z zawodu. Takie stricte rynkowe podejście do zawodu nauczycielskiego nieść może za sobą niebezpieczeństwo, że stanie się on zawodem drugorzędnego wyboru. Osoby, które nie sprawdzą się w realiach gospodarczych, będą trafiały do szkół. Trend ten wydaje się szczególnie niepożądany w edukacji zawodowej i w odniesieniu do nauczycieli kształcenia zawodowego.

Jak wynika z powyższego, rozbieżność stanowisk i oczekiwań społecznych jest biegunowo odmienna. Wobec tak różnych wymagań zasadne wydaje się pytanie o podstawowe prerogatywy tego zawodu.

7 J. Habermas, Teoria i praktyka. Wybór pism, Państwowy Instytut Wydawniczy, Warszawa 1993. 
Literatura pedagogiczna podaje wiele odpowiedzi na to pytanie. W warunkach współczesnej zmienności, niepewności, braku autorytetów, pejoratywności przestrzegania norm oraz życia społeczeństwa opartego na dobrowolności, nauczyciele uznawać winny prawo do wolności swoich wychowanków, ale również odnosić je do siebie. Wychowawca, jako podmiot praw i zobowiązań, ponosić winien osobistą odpowiedzialność za własne działania pedagogiczne. Wymagania roli, to transformatywny intelektualista, który pełni służbę w dyskursie wolności i wartości. Jak twierdzi Artur Bruhlmeier, ma być on „rzecznikiem porządku wartości absolutnych" . Praktyczna adaptacja tej koncepcji niesie za sobą obietnicę pozytywnych zmian w obszarze edukacji i wychowania. Wspomina o tym również Leszek Kołakowski, pisząc: „Potrzeba nam czegoś więcej, co nie może być ubocznym produktem instytucjonalnych i technologicznych ulepszeń - potrzeba nam reorientacji zarówno indywidualnej, jak i zbiorowego podejścia do wartości”. Pomimo że wartości są „abstrakcyjnymi pojęciami mówiącymi o tym, co społeczeństwo uważa za dobre, słuszne i pożądane"10 $\mathrm{w}$ ich urzeczywistnieniu człowiek powinien wykraczać poza swoją jednostkowość i kierować się ku społeczeństwu. Między innymi chodzi o przygotowanie młodych ludzi do ustawicznego poszukiwania, a nawet do podejmowania ryzyka w kreowaniu swojej wizji świata. Jest to ogromny wysiłek i wiąże się z nieustanną konfrontacją między bezpieczną adaptacyjną formą życia a dążeniem do poszukiwania nowej, niekonwencjonalnej i indywidualnej ścieżki.

Bogdan Suchodolski pisze:

W akceptacji rzeczywistości wyraża się ludzka potrzeba pewności i trwałości form istnienia, potrzeba zaufania i szczęścia wynikających z powtarzalnego uczestnictwa w tym, co dobrze znane, bardziej swojskie, zabezpieczające przed chaosem i niepewnością rzeczy nowych. Ale w przekraczaniu czy odrzucaniu tej rzeczywistości manifestuje się śmiałość i ryzyko, nieustępliwa wola szukania innych kształtów życia, choćby za cenę klęsk i rozczarowań, dumne przekonanie, iż godne akceptacji jest tylko to, co osiągamy, i tylko tak długo, jak to osiągamy ${ }^{11}$.

8 B. Śliwerski, Współczesne teorie i nurty wychowania, Oficyna Wydawnicza „Impuls”, Kraków 2010, s. 111.

9 L. Kołakowski, Niepewność epoki demokracji, Wydawnictwo Znak, Kraków 2017, s. 207.

10 N. Goodman, Wstęp do socjologii, Wydawnictwo Zysk i S-ka, Poznań 1997, s. 40.

11 B. Suchodolski, Wychowanie i strategia życia, WSiP, Warszawa 1983, s. 116. 
Inną niezmiernie ważną kwestią, na którą nauczyciele winni być uwrażliwieni, to kształtowanie u uczniów potrzeby i postaw wobec niezbywalnej wartości, jaką jest wolność. Chodzi tu nie tylko o to, by rozumieć potrzebę wolności, ale umieć o nią zabiegać i korzystać z niej w codziennym życiu. Jest to zagadnienie o tyle ważne, gdyż wiele źródeł naukowych podaje, że często ludzie niechętnie chcą korzystać z przypisanej im wolności i jak to określił Fiodor Dostojewski, „najbardziej męczącą troską człowieka jest to: znaleźć kogoś, komu można jak najprędzej oddać dar wolności, z którym ta nieszczęsna istota się rodzi”" Poza tym, jak uczyć wolności uczniów w sytuacji funkcjonowania w ściśle określonej strukturze? Fenomen ucieczki współczesnych ludzi od wolności analizował Erich Fromm: „Czyż wolność od wszystkich pierwotnych więzów czyni człowieka tak samotnym i izolowanym, że musi on niechybnie uciekać w nowe więzy"13. Z nadzieją badacz pisał dalej, że istnieje ,jakiś stan wolności pozytywnej, w którym jednostka żyje jako niezależne «ja» i nie tylko nie jest izolowana, lecz przeciwnie jest zjednoczona ze światem, z innymi ludźmi, z przyrodą"14. Na tym powinna polegać tajemnica wychowania, które nie powinno „zaciągać ludzi w niewolę, lecz powinno czynić człowieka dojrzałym do tego, by w sposób wolny wybierał i kształtował wartościową drogę swego życia”"15. Rzeczywistość wskazuje jednak, że ciągle trwa konflikt między wiernością a twórczością, między adaptacją a innowacją, między tym, co jest a tym, co być może. Zdaniem Barbary Skargi „Człowiek wolny i dzielący wolność z innymi zobowiązuje się do troski o innych, o całość społecznego bytu i jego racjonalne urządzenie. Obywatel na równi z innymi tworzy prawa społeczne i domaga się ich przestrzegania" ${ }^{16}$. Niewiara we własną wolność wystarcza, by upodlenie człowieka stało się pełne ${ }^{17}$.

Kończąc należy zaakcentować, że w publicznych i naukowych debatach na ogół na plan pierwszy wysuwane są zagrożenia, które realnie

12 F. Dostojewski, Bracia Karamazow, Państwowy Instytut Wydawniczy, Warszawa 1978, s. 308.

13 E. Fromm, Ucieczka od wolności, Wydawnictwo Czytelnik, Warszawa 1970, s. 242.

14 Ibidem.

15 B. Suchodolski, Wychowanie..., s. 20.

16 Hasło: Barbara Skarga, [w:] A. Klich (red.), Lapidarium mistrzów, Biblioteka „Gazety Wyborczej", Warszawa 2011, s. 180.

17 L. Kołakowski, Nasza wesoła apokalipsa, Wydawnictwo Znak, Kraków 2010, s. 204. 
mogą wpływać na jakość i kształt życia społecznego. Z drugiej strony, to $\mathrm{w}$ edukacji upatruje się szansę na minimalizowanie społecznego ryzyka i niepowodzeń. Jak stwierdza Bogusław Śliwerski, „chodzi o to, by edukacja stawała się czynnikiem czy instrumentem samoregulacji społecznej, sprzyjającej rozwojowi systemu społecznego i rozwojowi ludzi"18. Dlatego też potrzebni są nauczyciele mądrzy, odważni w swoim działaniu i myśleniu, otwarci na różnorodność i odmienność, innowacyjni i wrażliwi na problemy innych.

\section{Współczesne teorie i wizje społeczeństwa-zarys problemu}

Świat społeczny jest $\mathrm{z}$ natury wieloznaczny. Tym samym zdarzeniom przez różne osoby nadawane są rozmaite interpretacje czy znaczenia. Najczęściej dokonuje się to przez pryzmat rozmaitych schematów, przyswojonych przez człowieka struktur wiedzy, sposobu rozumienia, konstrukcji i rekonstrukcji sądów. Posługiwanie się znanymi schematami ułatwia funkcjonowanie człowieka w świecie społecznym. Co jednak się zdarzy, gdy zmienność życia społecznego nie pozwala na utrwalanie się tych schematów? Czy człowiek zdany jest na chaos, brak punktów odniesienia, nieprzewidywalność zdarzeń i brak rozumienia tego, co nas otacza? Jednoznaczną odpowiedź na te pytania trudno odnaleźć zarówno w źródłach naukowych, jak i potocznym myśleniu i działaniu. W literaturze przedmiotu łatwiej jest natknąć się na rozmaite opisy rzeczywistości społecznej niż jej jednoznaczną interpretację. W obszar życia społecznego „wrzucono” takie pojęcia, jak „płynne społeczeństwo” czy „płynne życie”"19, w którym warunki życia człowieka stale ulegają zmianom i brak jest jakichkolwiek punktów orientacyjnych, wyznaczających kierunki przyszłości. W podobnej konwencji odczytać można stanowisko Piotra Sztompki ${ }^{20}$ o „społecznym stawaniu się", gdzie życie społeczne toczy się w warunkach permanentnych zmian, nic nie dzieje się samoczynnie i jest efektem podmiotowego sprawstwa jednostek. Znany jest także pogląd Ulricha

18 B. Śliwerski, Problemy współczesnej edukacji. Dekonstrukcja polityki oświatowej III RP, Wydawnictwa Akademickie i Profesjonalne, Warszawa 2009, s. 330.

19 Patrz Z. Bauman, Płynne życie, Wydawnictwo Literackie, Kraków 2007 i inne pozycje tego autora.

20 Patrz P. Sztompka, Socjologia zmian społecznych, Wydawnictwo Znak, Kraków 2007. 
Becka $^{21}$ o „społeczeństwie ryzyka”, w którym każde działanie ludzkie obciążone jest ryzykiem, a jego poziom wzrasta wraz z poziomem wykształcenia człowieka. Natomiast Richard Sennett ${ }^{22}$ zapowiada koniec „człowieka publicznego" ponieważ obecne modele zarządzania organizacjami zabijają w pracownikach lojalność, solidarność czy wspólnotowość. Z kolei Anthony Giddens ${ }^{23}$ pisząc o nowoczesności wprowadził pojęcie „refleksyjność instytucjonalna”, pod którym kryje się zrywanie z przejawami rutyny w życiu społecznym oraz zdolność ludzi do refleksji nad własnymi warunkami życia i wykorzystania jej do planowania przyszłości. Kończąc to zagadnienie warto jeszcze przywołać „krytyczną teorię społeczną” Jurgena Habermasa ${ }^{24}$, w której autor stara się aktywnie włączyć w dyskurs na temat wyzwań, jakie stawia globalizacja ekonomiczna, w tym problemy polityczne i etyczne związane ze stopniowym odejściem od skali narodowej oraz jak w tej sytuacji można zagwarantować poszanowanie praw człowieka. Do słownika socjologicznego Manuel Castells wprowadził określenie „społeczeństwo sieci". Jego zdaniem:

Nowa technologia informacyjna przedefiniuje procesy pracy i role samych pracowników, a co za tym idzie strukturę zatrudnienia i zawodów. Wzrost wyuczonych kwalifikacji, ogólnych lub specjalistycznych, wymaganych na nowych, przekształconych stanowiskach struktury zawodowej, jeszcze bardziej przyczynia się do segregacji siły roboczej według kryterium wykształcenia, które samo wiąże się z systemem wysoce obciążonym segregacją ${ }^{25}$.

Nawiązując do konwencji Manuela Castellsa w literaturze i dyskursach publicznych pojawia się określenie „społeczeństwo informacyjne", w którego ramach dominujący staje się sektor informacyjny, a dostęp do informacji staje się powszechny. Dalej mówi się o społeczeństwie „rynkowym”, gdzie człowiek traktowany jest jedynie jako uczestnik gier rynkowych opartych na prawach „popytu” i „podaży”.

21 Patrz U. Beck, Społeczeństwo ryzyka. W drodze do innej nowoczesności, Wydawnictwo Scholar, Warszawa 2004.

22 R. Sennett, Razem. Rytuały, zalety i zasady współpracy, Wydawnictwo Literackie Muza, Warszawa 2013.

23 A. Giddens, Europa w epoce globalnej, PWN, Warszawa 2009, s. 84.

24 Patrz J. Habermas, Strukturalne przeobrażenia sfery publicznej, PWN, Warszawa 2008.

25 Patrz M. Castells, Społeczeństwo sieci, PWN, Warszawa 2013, s. 240. 
Podobnych przymiotnikowych dookreśleń społeczeństwa w literaturze, jak i publicznych dyskursach jest wiele.

Rozważając tezy zawarte w książce Patricka Bearta i Filipe Carreira da Silva pt. Teorie społeczne w XX wieku i dzisiaj ${ }^{26}$ współczesną teorię społeczną podzielić można na dwa wyraźnie różniące się nurty. Najkrócej rzecz ujmując pierwszy z nich rysuje dość pesymistyczną wizję życia współczesnego człowieka. Stawiane są w nim tezy o jego zagubieniu we współczesnym świecie, o alienacji, braku trwałych punktów odniesienia, braku poczucia bezpieczeństwa i zatracaniu się w łatwych wzorcach zachowań, np. w konsumeryzmie. W takim duchu odczytywać można m.in. prace Zygmunta Baumana, Ulricha Becka, Anthony'ego Giddensa, Richarda Sennetta czy Ericha Fromma. Zdaniem tych badaczy, trudne życie społeczne wynika m.in. z przemian gospodarczych, w tym ze sposobu zatrudniania i zwalniania pracowników, procesów globalizacyjnych, z rezygnacji wielu państw z rzeczywistej opieki nad swoimi obywatelami, np. poprzez prawodawstwo związane z rynkiem pracy oraz nieprzystosowaniem systemów edukacji do zachodzących przemian społeczno-gospodarczych i do związanych z tym potrzeb środowisk społecznych.

Drugi nurt teoretycznych rozważań na temat stanu współczesnego społeczeństwa niesie ze sobą pozytywną obietnicę postępu. Są to stanowiska, które uzasadniają konieczność dokonujących się zmian techniczno-technologicznych i ich pozytywnych konsekwencji dla jakości życia społecznego. Wspomniany wyżej M. Castells sformułował pojęcie „społeczeństwa sieciowego”, które cechuje transgraniczność, wielotożsamość czy kosmopolityzm. Jego istotą jest natomiast sieć relacji społecznych oraz swobodny dostęp do uczestniczenia w różnych organizacjach i grupach społecznych czy kręgach zainteresowań przez jednostkę. Za istotny czynnik zmian uważa się rozwój nowoczesnych technologii telekomunikacji oraz rozbicie tradycyjnych form interakcji ludzkich. Zdaniem M. Castellsa, analiza ewolucji zatrudnienia ujawnia pewne cechy wspólne, które wydają się charakteryzować społeczeństwo informacyjne. Są to m.in. ograniczenia tradycyjnych form zatrudnienia, wzrost znaczenia usług i ich dywersyfikacja,

26 P. Baert, F. Carreira da Silva, Teorie społeczne w XX wieku i dzisiaj, Zakład Wydawniczy NOMOS, Kraków 2013. 
przyrost zawodów menadżerskich, specjalistycznych i technicznych, podwyższanie struktury zawodowej27. W podobnej konwencji odczytywać można pojęcie „społeczeństwa wiedzy”, w którym wiedza traktowana jest jako zasób strategiczny. W społeczeństwie tym duże znaczenie przypisuje się wiedzy naukowej, sprofilowanej praktycznie oraz rozwojowi intelektualnemu. Przyjmuje się, że społeczeństwo wiedzy powstaje na podłożu nowych technik informatycznych po to, aby mądrze wykorzystywać narastające pokłady informacji do realizowanych celów, które ludzie uznają za pożądane.

Jak wynika z zarysowanych wyżej koncepcji i nurtów teorii społecznych współczesny świat oferuje zarówno szereg możliwości, jak i strat. Charakteryzuje się, zdaniem Piotra Sztompki ${ }^{28}$, pewnymi fundamentalnymi właściwościami. Są nimi m.in.: ambiwalencja, niejednoznaczność występujących tendencji i stojących za nimi wartości, a często ich wzajemna przeciwstawność. Dlatego należy mówić o dylematach, które stają się immanentną cechą współczesności. Badacz rozpatruje dziesięć dylematów i wyzwań dla przyszłości społeczeństw w XXI wieku: indywidualizm czy wspólnota? Globalizacja czy tożsamość lokalna? Interesy czy wartości? Społeczeństwo masowe czy jakość życia? Kult nowości czy afirmacja tradycji? Dorywcze zajęcia czy życiowa kariera? Konsumpcja czy samorealizacja? Kontraktowa intymność czy trwała rodzina? Demokracja w rękach wybranych czy dyskurs polityczny? Informacja czy mądrość?

Zdaniem P. Sztompki w obecnym kształcie życia społecznego dominują akcenty wymienione jako pierwsze. Wydaje się, że indywidualizm, interesowność, masowość, kult nowości, dorywczość pracy, konsumpcjonizm, kontraktowa intymność, idea demokracji elitarnej i fetysz informacji nadają sens życiu społecznemu. Szansą na zmianę tego trendu, jest czynnik, określany przez socjologów jako „społeczna refleksyjność". Chodzi o to, że ludzie dysponują możliwością świadomej refleksji nad swoją sytuacją i kierunkiem, w jakim zmierza świat. Jest to nadzieja na pozytywny rozwój społeczny i alternatywa dla życia zorientowanego tylko na materialną stronę, bowiem, jak pisze Ryszard Kapuściński: „Boję się świata bez wartości, bez wrażliwości, bez myślenia. Świata, w którym wszystko jest możliwe. Ponieważ wówczas

27 M. Castells, Społeczeństwo..., s. 251.

28 P. Sztompka, Dziesięć dylematów XXI wieku, „Wprost” 2003, nr 1. 
najbardziej możliwe staje się zło”29. Na scenie współczesności każdy z nas ma świadomość potęgi narzędzi, które posiada. „Jesteśmy aktorami w wielkim teatrze świata, ale kiedy wszystkie reflektory zwracają się na nas, jak obuchem uderza nas ideacyjna agnozja"30.

Zmienność świata społecznego, jego teoretycznych i praktycznych odniesień dotyczy również obszaru psychologii społecznej, w którym rozpatrywane są takie pojęcia, jak przynależność społeczna, kontrola, objaśnianie sensów życia, kapitał społeczny, zaufanie społeczne czy cynizm społeczny. Dwa ostatnie pojęcia, silnie skorelowane, są ideologiami tragicznej i humanistycznej wizji człowieka. W pierwszej, człowiek jest egoistyczny i jak twierdził Tomasz Hobbes „życie człowieka jest samotne, nędzne, wstrętne, brutalne i krótkie"31. W ideologii humanistycznej mającej swe korzenie w teorii dobra Arystotelesa ${ }^{32}$ człowiek jest z natury szlachetny i cnotliwy, a współpraca z innymi jest jego powołaniem. W humanistycznej wersji człowieka umieścić można zaufanie społeczne, które polega na założeniu, że większość osób jest uczciwa, pomocna oraz godna zaufania. Wysokiemu zaufaniu społecznemu towarzyszy wiele korzystnych zjawisk społecznych, takich jak zadowolenie $\mathrm{z}$ demokracji, działalność na rzecz bezpośredniego otoczenia społecznego, udział w wyborach, wspieranie dobroczynności czy zawieranie większej liczby przyjaźni. Generalnie rzecz ujmując jest to zjawisko budujące wspólnotowość społeczną. Natomiast cynizm społeczny, czyli negatywny pogląd na naturę ludzką, wyraża przekonanie, że ludzie łatwo ulegają deprywacji, są egoistyczni i leniwi. Społeczeństwo takie cechuje wiara w negatywne stereotypy, łamanie zasad moralnych, rywalizacja, szybkie tempo życia, obniżona satysfakcja z życia i pracy zawodowej. Cynizm społeczny porównać można do gry o sumie zerowej: jeśli ktoś ma wygrać, to ktoś inny musi przegrać.

29 R. Kapuściński, Lapidaria, Wydawnictwo Czytelnik, Warszawa 2006, s. 323.

30 Z. Bauman, T. Leoncini, Ptynne pokolenie, Wydawnictwo Czarna Owca, Warszawa 2018, s. 109.

31 T. Hobbes, Lewiatan czyli materia, forma i władza państwa kościelnego i świeckiego, PWN, Warszawa 1954, s. 51.

32 Dla Arystotelesa miarą słuszności był żywy wzór dobrego i mądrego człowieka. Patrz W. Tatarkiewicz, Historia filozofii, t. 1, PWN, Warszawa 1978, s. 118 i in. 
Odnosząc te problemy do Polski, to jak pokazuje wiele badań społecznych ${ }^{33}$, Polaków cechuje niski poziom zaufania do ludzi w ogóle. Jak informują autorzy Diagnozy Społecznej 2015².

Społeczeństwo obywatelskie w Polsce rozumiane jako udział w organizacjach dobrowolnych oraz włączanie się Polaków w jakieś działania na rzecz własnej społeczności, jest na bardzo niskim poziomie. Ponadto akceptacja demokracji, jako ustroju politycznego, jest niewielka. Natomiast między rokiem 2011 a 2015 o jedną czwartą wzrosły postawy ksenofobiczne Polaków.

Wśród wielu przyczyn tego typu postaw wymienia się dwie podstawowe - materializm i doświadczenia generujące nieufność. W trudnym okresie transformacji społeczeństwo polskie najłatwiej przejęło z „zachodu” najprostsze formy dobrobytu - zwiększoną konsumpcję i nastawienie na zysk za wszelką cenę. Druga przyczyna, będąca jeszcze w pamięci wielu Polaków, to historyczne doświadczenia, czyli powszechna bieda, gospodarka niedoboru oraz życie w systemie opartym na powszechnym kłamstwie. Jest to poważny problem, ponieważ powszechna nieufność hamuje, m.in. procesy przedsiębiorczości, wykrzywia i deformuje obrazy życia społecznego. Jak pisze Bogdan Wojciszke: „spostrzegany świat społeczny człowieka jest w dużej części wytworem jego umysłu, a właściwie wytworem umysłów społeczności, w której człowiek żyje i która nadaje mu określoną tożsamość" ${ }^{35}$. Stąd też duże nadzieje pokładane w edukację i nauczycieli, że potrafią przełożyć na język społeczny i rozszyfrować symbolikę zmian, procesów, zjawisk, jakie nieustannie towarzyszą współczesnemu człowiekowi, by uchronić go przed manowcami i być dla nich racjonalną podporą. „Największą z ludzkich mocy jest ta, na którą składa się moc wielu ludzi złączonych umową w jedną osobę fizyczną czy prawną, która posługuje się wszystkimi mocami jednostek zależnie od swej woli”36.

33 Patrz m.in. J. Czapiński i T. Panek (red.), Diagnoza Społeczna 2015, Vizja Press, Warszawa 2015 oraz K. Skarżyńska, Człowiek i polityka. Zarys psychologii społecznej, seria Wykłady z Psychologii, t. 13, Wydawnictwo Scholar, Warszawa 2005.

34 J. Czapiński, T. Panek (red.), Diagnoza Społeczna 2015..., s. 322-325.

35 B. Wojciszke, Psychologia społeczna, Wydawnictwo Scholar, Warszawa 2013, s. 111.

36 T. Hobbes, Lewiatan czyli materia..., s. 74. 


\section{Społeczne role nauczycieli w warunkach zmienności społecznej - misyjność, służba, zadaniowość czy...}

Zarysowane wyżej problemy życia środowisk społecznych, jak i indywidualnych losów, mają swoje przełożenie m.in., na systemy, za pomocą których państwo reguluje swoje funkcjonowanie. Chodzi o systemy polityczne, ekonomiczne, ochrony zdrowia, pomocy społecznej czy edukacyjne. Jak zauważa Joanna Szempruch, w kontekście dynamicznych zmian społecznych szkoła staje się miejscem nie tylko twórczego poszukiwania i samodzielnego konstruowania obrazu świata, ale staje się środowiskiem życia społecznego młodzieży przebiegającego według wzorów kulturowych wyznaczonych przez szkołę i jej społeczne otoczenie ${ }^{37}$. Wokół niej tworzy się określony klimat społeczny związany z potrzebami i oczekiwaniami, hierarchią wartości i transmisją kulturową, komunikacją, reprodukcją ustalonego ładu społecznego. Coraz częściej postrzega się szkołę jako miejsce, w którym rozgrywa się większość relacji społecznych związanych z kulturą, rozpowszechnianiem wiedzy i informacji, aktywności sportowej czy miejscem, w którym świadczy się rozmaite usługi o charakterze edukacyjnym. Zwłaszcza w lokalnym wydaniu szkoła staje się płaszczyzną transgresji wiedzy teoretycznej, „lakmusową” przestrzenią społecznego kształcenia powszechnego, w której nadawany jest, przez rodzinę i szkołę, kształt osobowości społecznej młodych ludzi.

Każdy z nas „oddaje” społeczeństwu to, co od niego wziął w procesie wzrastania $\mathrm{w}$ to społeczeństwo w rodzinie, w szkole, wśród rówieśników (...) trzeba więc dobrze zdawać sobie sprawę z tego, co się wzięło. Lecz oryginalnego wkładu w dorobek społeczny możemy wnieść tylko tyle, ile możemy wypromieniować z własnej niepowtarzalnej indywidualności. Bez refleksji nad korzeniami tej indywidualności dla siebie nie zdefiniujemy i nie potrafimy sami określić ${ }^{38}$.

Uznając szkołę za czynnik socjalizujący Zbyszko Melosik stwierdza, że:

$\overline{37}$ J. Szempruch, Nauczyciel w warunkach zmiany społecznej i edukacyjnej, Oficyna Wydawnicza „Impuls”, Kraków 2012, s. 8.

38 J. Szczepański, Korzeniami wrosłem w ziemię, Wydawnictwo Śląsk, Katowice 1984, s. 8. 
rozwija zaangażowanie jednostki na rzecz wartości społecznych i na rzecz wypełniania ról społecznych; wyposaża ją również w techniczne kwalifikacje i społeczne „umiejętności”, będąc tym samym środkiem „podtrzymywania” systemu kulturowego. Edukacja jest jednak także - w jej funkcji selekcyjnej - środkiem dostarczania odpowiedniego „materiału ludzkiego” dla struktury społecznej39.

W kontekście opisywanej wyżej zmienności społecznej, refleksji wymaga problem ról nauczycielskich, zwłaszcza społecznych. Pojęcie roli społecznej sformułował Robert Merton. Jego zdaniem, każdy człowiek funkcjonujący w określonym środowisku społecznym posiada przypisaną przez to środowisko, rolę społeczną wynikającą z organizacji danego społeczeństwa. Stąd też „ Rola społeczna zakłada zbiór norm i wartości związanych z określoną pozycją społeczną"40. Rola społeczna jest zatem wyznaczana w momencie obecności w strukturze społecznej, niezależna od woli jednostki wkraczającej fizycznie w społeczność, spójna z innymi rolami społecznymi ${ }^{41}$. W opinii Krzysztofa Rubachy ${ }^{42}$ pełniona rola społeczna generuje normatywne postrzeganie oczekiwane wobec osób wykonujących dane role. Należy mieć na uwadze, że współcześnie pełnienie jednej roli jest niemożliwe. Każdy człowiek przynależy jednocześnie do wielu społecznie zróżnicowanych kategorii, grup i struktur społecznych. Społeczną rolę nauczyciela można też przedstawić jako system normatywnych powiązań pomiędzy jednostką a częścią środowiska społecznego. Jak pisze Florian Znaniecki, system ustala funkcję społeczną, czy zespół obowiązków, któremu jednostka musi sprostać, warunkuje jej jaźń społeczną, tj. obraz tego, czym winna być w oczach innych i dla siebie jako istota cielesna i psychiczna: ustanawia jej stan socjalny, czyli zespół praw, jaki ma jej przyznawać dany krąg społeczny oraz ustala jej funkcję społeczną ${ }^{43}$. Rozpatrywanie roli społecznej, jak zauważa K. Rubacha,

39 Z. Melosik, Funkcjonalno-strukturalna interpretacja edukacji, [w:] T. Gmerek (red.), Edukacja i stratyfikacja społeczna, Wydawnictwo Wolumin, Poznań 1993, s. 83.

40 Cyt. za H. Kwiatkowska, Pedeutologia, Wydawnictwa Akademickie i Profesjonalne, Warszawa 2008, s. 37.

41 Ibidem.

42 K. Rubacha, O społecznej roli nauczyciela w świetle teorii indywidualnej Levinsona, „Teraźniejszość - Człowiek - Edukacja. Kwartalnik Myśli Społeczno-Pedagogicznej" 2001, nr 4, s. 39-57.

43 F. Znaniecki, Społeczne role uczonych i historyczne cechy wiedzy, [w:] F. Znaniecki (red.), Społeczne role uczonych, PWN, Warszawa 1984, s. 530-531. 
z perspektywy organizacji społecznej, kładzie nacisk na możliwe statusy, wokół których każdy człowiek wypełnia swoją rolę. Rodzi to oczekiwania dotyczące zachowań w stosunku do osób wykonujących dane role. Dla identyfikacji roli społecznej nauczyciela ważne jest rozróżnienie między jednostką a społeczeństwem. Rola indywidualna staje się wypadkową społecznych nakazów roli i subiektywnej interpretacji przepisu przez jednostkę ${ }^{44}$. Kontynuując ten wątek można też, za Iwanem Illichem, stwierdzić, że „W strukturze systemu oświatowo-społecznego nauczanie stapia się z przydziałem ról społecznych"5.

Prezentowane wyżej opinie dają podstawę, aby wysnuć wniosek, że na status społeczny roli nauczyciela wpływ może mieć pozycja w hierarchii społecznej nauczyciela, zespół normatywnych zobowiązań, subiektywna interpretacja przepisu roli przez nauczyciela oraz potrzeby i oczekiwania zewnętrznego środowiska.

Fenomenem społecznej aktywności nauczyciela, jego relacji z uczniami i społecznymi grupami środowiskowymi, jego podmiotowej i przedmiotowej działalności zawrzeć można w idei przywództwa edukacyjnego, gdzie rola społeczna jest podstawą aksjologiczną, warunkiem innowacji kulturowej i pedeutologiczną afirmacją autorytetu. Henryka Kwiatkowska ${ }^{46}$ patrząc na nauczyciela z perspektywy podmiotowego sposobu bycia w świecie, wskazuje na trzy sposoby jego zawodowego funkcjonowania. Pierwszy z nich to bycie w roli, gdzie wykonanie przepisu roli jest tożsame ze spełnieniem nauczycielskich zobowiązań zawodowych. Drugi sposób funkcjonowania w zawodzie to bycie autonomicznym podmiotem. Bycie sobą i bycie nauczycielem nie kolidują ze sobą. Trzeci sposób to bycie bezrefleksyjnym. Cechą tego sposobu bycia jest powierzchowność w odbiorze rzeczywistości pedagogicznej, przy braku pogłębionej interpretacji i rozumienia faktów. Autorka analizuje role nauczycielskie przez pryzmat tożsamościowy. Wskazuje na tożsamość anomijną, która w działaniu pedagogicznym występuje wówczas, gdy nauczyciel w pracy koncentruje się głównie na własnym interesie. Kolejna sprawa to tożsamość roli,

\footnotetext{
$44 \quad$ K. Rubacha, O społecznej roli..., s. 39.

45 I. Illich, Społeczeństwo bez szkoły, Państwowy Instytut Wydawniczy, Warszawa 1974, s. 44.

46 H. Kwiatkowska, Edukacja nauczycieli: konteksty-kategorie-praktyki, IBE, Warszawa 1997, s. 74-75.
} 


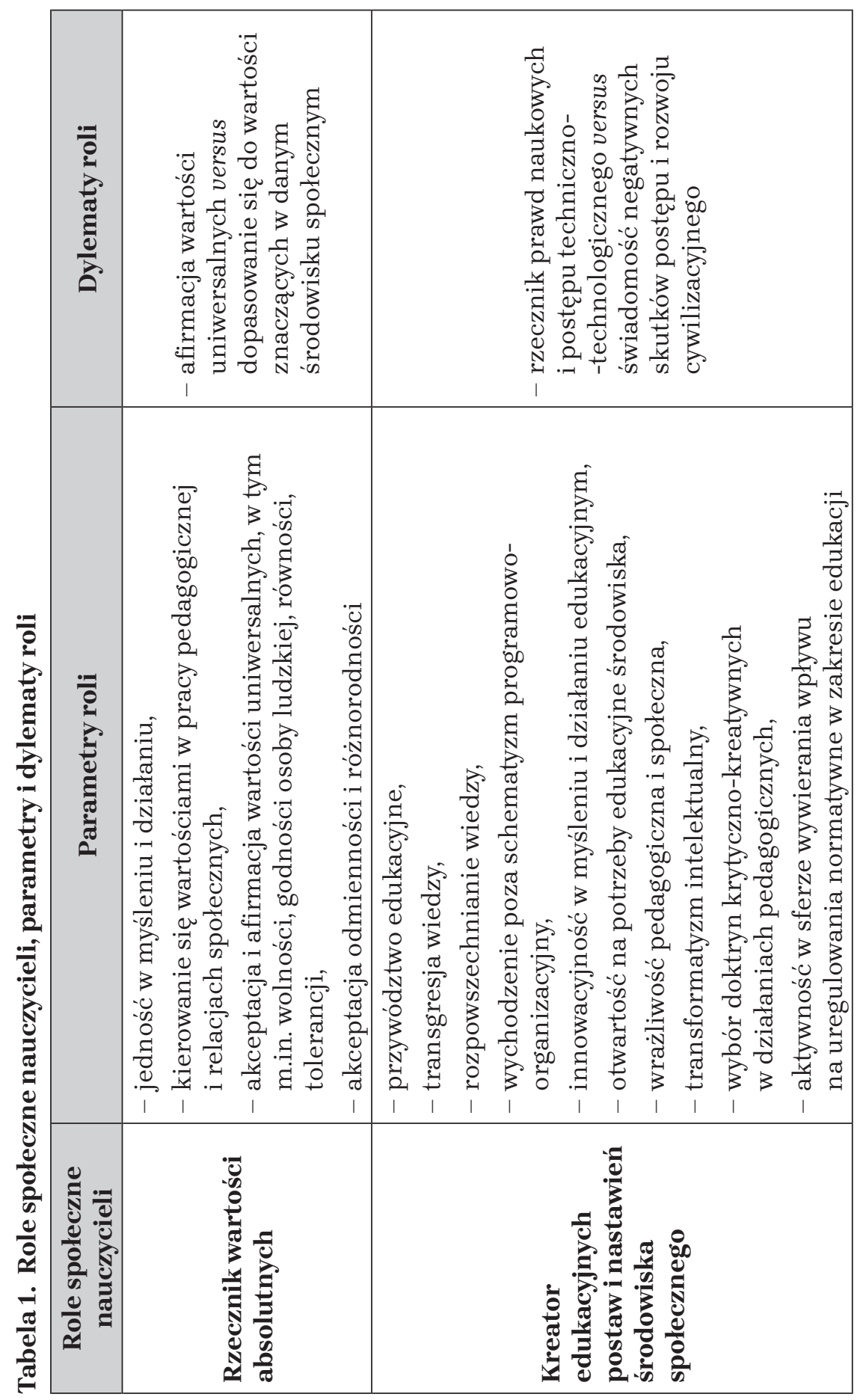




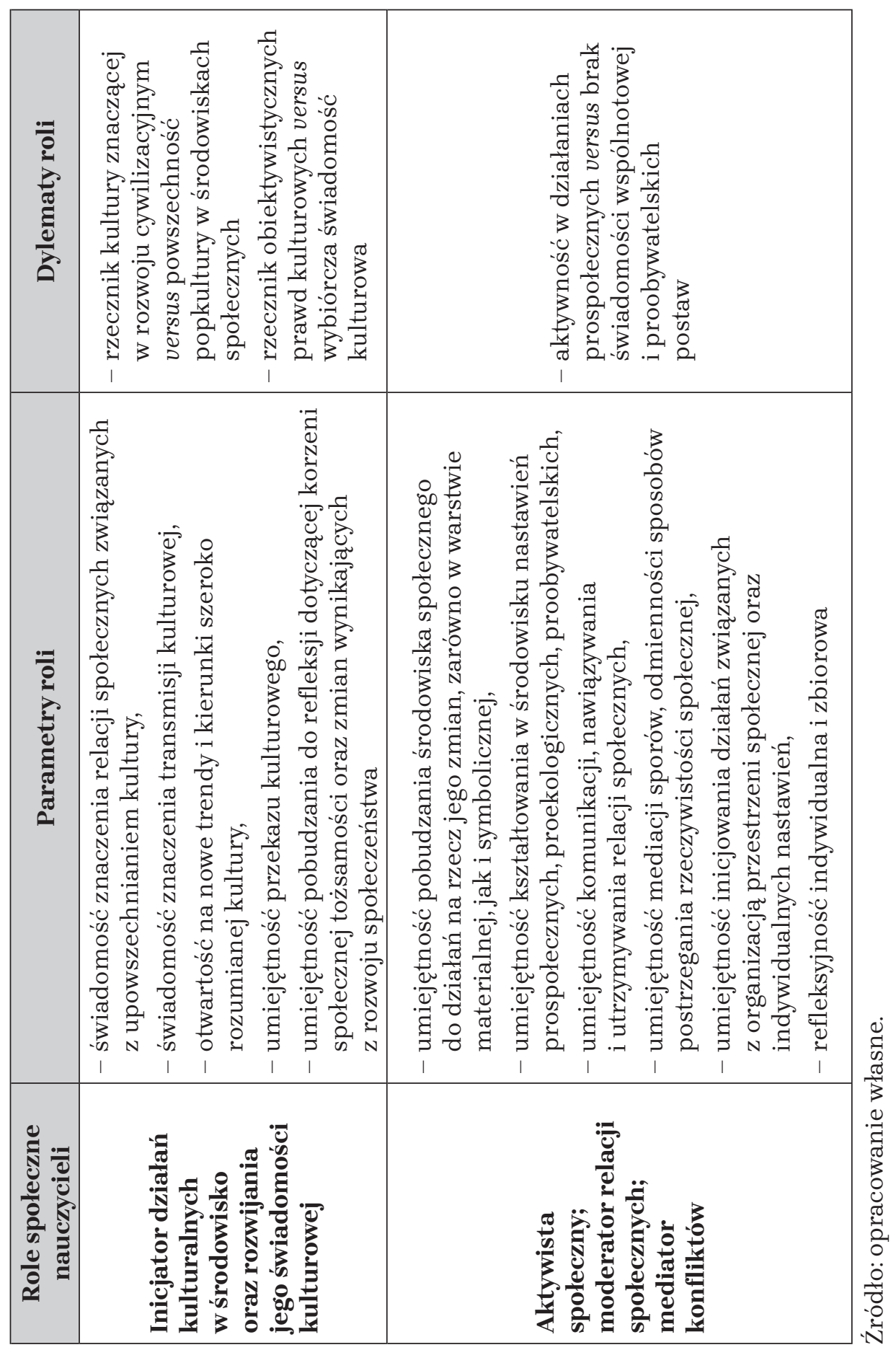


która w pracy nauczyciela przejawia się dążeniem do zadośćuczynienia w spełnianiu wszelkich zobowiązań przepisu roli. Dalej chodzi o tożsamość autonomicznego „Ja”, która zaznacza potrzebę i zdolność do działań we własnym imieniu i na własną odpowiedzialność. Tożsamość ta zakłada uczestnictwo w definiowaniu sytuacji i warunków działania, wywierania wpływu na uregulowania normatywne. Nauczyciel o tej tożsamości nie poddaje się biernie konwencji, dąży do wywierania wpływu na bieg zdarzeń ${ }^{47}$.

Rekapitulując wybrane stanowiska teoretyczne, jak i doświadczenia pragmatyki edukacyjno-społecznej można sformułować kilka, najbardziej charakterystycznych ról społecznych nauczycieli. Analizując je nietrudno odnieść wrażenie, że nawiązują one do wartości maksymalnych i zapewne w pragmatyce oświatowej trudno osiągalnych. Ale jak inaczej formułować je skoro wokół rzeczywistość stawia przed ludźmi ogromne wyzwania i karze być nastawionym na sukces.

Zaproponowany katalog ról społecznych nauczycieli jak i jego konfiguracja jest kwestią otwartą. Jego zawartość może być zmienna w zależności od tego, jak będzie zmieniało się środowisko społeczne nauczyciela oraz jak będzie reagował na te zmiany. Nie ulega wątpliwości, że czynniki środowiskowe, takie jak poziom społecznego wewnętrznego zorganizowania, aspiracje, potrzeby, oczekiwania, a także poziom ekonomicznego rozwoju czy nawet usytuowanie geograficzne znacząco oddziaływać może na zachowania i postawy nauczycieli. Nie ulega wątpliwości również, że stymulujące otoczenie wpływa na pozytywną motywację i pobudza do działania. Środowisko takie otwiera nauczycielom możliwość autonomii w działaniu i myśleniu, postępowania zgodne $\mathrm{z}$ własnym i uniwersalnym systemem wartości, a także uświadamia, że przyszłość ich uczniów zależy w dużej mierze od nich samych. Sprzyja to nastawieniu misyjnemu nauczycieli do pracy w szkole i poza nią. Natomiast środowisko apatyczne, bez dążeń i oczekiwań, życiowo zorientowane na filozofię „tu i teraz”, dezawuować może każdą aktywność, nauczycieli również. W takich okolicznościach nauczyciele ograniczają się najczęściej tylko do spełniania podstawowych obowiązków, a w ich świadomości kreuje się myśl, że przyszłość uczniów leży poza ich mocą i kontrolą. Umacnia to służbową formułę

47 H. Kwiatkowska, Tożsamość nauczycieli: między anomią a autonomią, GWP, Gdańsk 2005, s. 85. 
nauczycielskiego zaangażowania, a więc postępowania zgodnego $\mathrm{z}$ regułami narzuconymi z góry lub zadaniową formułę, czyli poruszanie się tylko w obrębie wykonywania zadań koniecznych, zleconych przez przełożonego.

Jakość realizowanych społecznych ról uwiarygodniać powinna osoba nauczyciela. Ale tak, jak dzieje się to w innych zawodach, również i w tym zawodzie są osoby oddane swojej pracy, ale również i takie, które trafiły do zawodu np. w wyniku negatywnej selekcji. Przyczynił się do tego zapewne boom edukacyjny w szkolnictwie wyższym, w tym również na studiach pedagogicznych. Temat ten porusza, m.in. Teresa Hejnicka-Bezwińska pisząc:

Jeżeli uwzględnimy jeszcze, że w Polsce nie ma certyfikatów ani egzaminów państwowych, dopuszczających do zawodu nauczyciela, to musimy uznać, że każdego roku mury różnych uczelni opuszcza ogromna liczba absolwentów legitymujących się formalnymi kwalifikacjami, uprawniającymi do zatrudnienia w instytucjach systemu oświatowego ${ }^{48}$.

Pytania o jakość kształcenia są otwarte. Niepokój w tym zakresie wyrażał, m.in. Bogusław Śliwerski, który uważa, że w dalszym ciągu aktualne są kwestie związane $\mathrm{z}$ podnoszeniem jakości pracy dydaktycznej przez samych nauczycieli, zwiększenia refleksji nad własnym działaniem, ustawiczne samokształcenie oraz przyczynianie się do zmiany kultury pracy szkoły ${ }^{49}$.

Zagadnienia ról nauczycielskich czy przypisywanych formuł jego pracy nie można jednoznacznie określać i nadać im charakter przypisu roli czy formuły pracy. Problemu tego nie rozstrzyga ani teoria pedeutologiczna ani pragmatyka edukacyjna. Zbyt wiele jest wyznaczników i układów odniesienia, by zamknąć pracę nauczyciela w jednej „czystej” formule czy przypisać mu ściśle określoną rolę. W społecznej roli nauczyciela wpisany jest bowiem problem edukacji społecznej, wychowawczego oddziaływania na różnego rodzaju środowiska, propagowania i egzekwowania spektrum kulturowego akceptowanego przez osoby dorosłe i młode pokolenie. Interesującym nawiązaniem

48 T. Hejnicka-Bezwińska, Praktyka edukacyjna w warunkach zmiany kulturowej, PWN, Warszawa 2015, s. 405.

49 B. Śliwerski, Problemy współczesnej edukacji. Dekonstrukcja polityki oświatowej III RP, Wydawnictwa Akademickie i Profesjonalne, Warszawa 2009, s. 328. 
do omawianego problemu jest społeczna ideia steinerowskiej edukacji, w której

nie należy pytać: co człowiek musi wiedzieć i umieć dla istniejącego porządku społecznego, lecz, do czego człowiek jest uzdolniony i co w nim można rozwiązać? Wtedy stanie się możliwe, aby dorastające pokolenia dostarczały społeczeństwu nowych sił. Wtedy, w takim porządku społecznym ciągle żyć będzie to, co uczynią z niego wkraczający do niego w pełni rozwinięci ludzie; natomiast nigdy z dorastającym pokoleniem nie czyni się tego, co chce z niego uczynić istniejący porządek społeczny ${ }^{50}$.

\title{
Zakończenie
}

Problematyka ról społecznych nauczycieli jest na tyle obecnie znaczącym problemem, iż wymaga wnikliwej analizy i to nie tylko na poziomie zbiorowym, ale chyba przede wszystkim biograficznym. Pragmatyka oświatowa wskazuje bowiem na to, że jest to grupa zawodowa wewnętrznie bardzo zróżnicowana. Przykładem tego są m.in. bardzo odmienne postawy i zachowania nauczycieli wobec strajku od aktywnego uczestnictwa poprzez bierność, aż do zdecydowanie krytycznego nastawienia i działania antystrajkowego. Dobrym sposobem zgłębienia tej problematyki może być analiza indywidualnych losów nauczycieli, ich prerogatyw, sposobu myślenia na temat osobistych ról oraz sposobów ich kreowania.

\begin{abstract}
The text is a reflection on the ongoing social changes and the role of the teacher in these processes. Contemporary social theories and their references to the pragmatics of social life have been described. A catalogue of teacher roles, which are expected from teacher by the changing social environment, was also formulated.
\end{abstract}

\section{Bibliografia}

Baert P., Carreira da Silva F., Teorie społeczne w XX wieku i dzisiaj, Zakład Wydawniczy NOMOS, Kraków 2013.

Bauman Z., Płynne życie, Wydawnictwo Literackie, Kraków 2007.

50 J. Prokopiuk, Pedagogika Rudolfa Steinera, [w:] J. Prokopiuk (red.), Labirynt herezji, Wydawnictwo Literackie MUZA S.A., Warszawa 1999, s. 170. 
Bauman Z., Leoncini T., Płynne pokolenie, Wydawnictwo Czarna Owca, Warszawa 2018.

Beck U., Społeczeństwo ryzyka. W drodze do innej nowoczesności, Wydawnictwo Scholar, Warszawa 2004.

Castells M., Społeczeństwo sieci, PWN, Warszawa 2013.

Czapiński J., Panek T. (red.), Diagnoza Społeczna 2015, Vizja Press, Warszawa 2015.

Dewey J., Moje pedagogiczne credo, PWN, Warszawa 2005.

Dostojewski F., Bracia Karamazow, Państwowy Instytut Wydawniczy, Warszawa 1978.

Fromm E., Ucieczka od wolności, Wydawnictwo Czytelnik, Warszawa 1970.

Giddens A., Europa w epoce globalnej, PWN, Warszawa 2009.

Goodman N., Wstęp do socjologii, Wydawnictwo Zysk i S-ka, Poznań 1997.

Gutek G.L., Filozofia dla pedagogów, GWP, Gdańsk 2007.

Habermas J., Teoria i praktyka. Wybór pism, Państwowy Instytut Wydawniczy, Warszawa 1993.

Habermas J., Strukturalne przeobrażenia sfery publicznej, PWN, Warszawa 2008.

Hejnicka-Bezwińska T., Praktyka edukacyjna w warunkach zmiany kulturowej, PWN, Warszawa 2015.

Hobbes T., Lewiatan czyli materia, forma $i$ władza państwa kościelnego i świeckiego, PWN, Warszawa 1954.

Illich I., Społeczeństwo bez szkoły, Państwowy Instytut Wydawniczy, Warszawa 1974.

Kapuściński R., Lapidaria, Wydawnictwo Czytelnik, Warszawa 2006.

Klich A. (red.), Lapidarium mistrzów, Biblioteka „Gazety Wyborczej”, Warszawa 2011.

Kołakowski L., Nasza wesoła apokalipsa, Wydawnictwo Znak, Kraków 2010.

Kołakowski L., Niepewność epoki demokracji, Wydawnictwo Znak, Kraków 2017.

Kwiatkowska H., Edukacja nauczycieli: konteksty - kategorie - praktyki, IBE, Warszawa 1997.

Kwiatkowska H., Tożsamość nauczycieli: między anomią a autonomią, GWP, Gdańsk 2005.

Kwiatkowska H., Pedeutologia, Wydawnictwa Akademickie i Profesjonalne, Warszawa 2008. 
Kwintylian M.F., Kształcenie mówcy, przekł. M. Brożek, Wydawnictwo Ossolineum, Wrocław 1951.

Melosik Z., Funkcjonalno-strukturalna interpretacja edukacji, [w:] T. Gmerek (red.), Edukacja i stratyfikacja społeczna, Wydawnictwo Wolumin, Poznań 1993.

Prokopiuk J., Pedagogika Rudolfa Steinera, [w:] J. Prokopiuk (red.), Labirynt herezji, Wydawnictwa Literackie MUZA S.A., Warszawa 1999.

Rubacha K., O społecznej roli nauczyciela w świetle teorii indywidualnej Levinsona, „Teraźniejszość - Człowiek - Edukacja. Kwartalnik Myśli Społeczno-Pedagogicznej" 2001, nr 4.

Sennett R., Razem. Rytuały, zalety i zasady wspótpracy, Wydawnictwo Literackie Muza, Warszawa 2013.

Skarżyńska K., Człowiek i polityka. Zarys psychologii społecznej, Wydawnictwo Scholar, Warszawa 2005.

Suchodolski B., Wychowanie i strategia życia, WSiP, Warszawa 1983.

Szczepański J., Korzeniami wrosłem w ziemię, Wydawnictwo Śląsk, Katowice 1984.

Szempruch J., Nauczyciel w warunkach zmiany społecznej i edukacyjnej, Oficyna Wydawnicza „Impuls”, Kraków 2012.

Sztompka P., Dziesięć dylematów XXI wieku, „Wprost” 2003, nr 1.

Sztompka P., Socjologia zmian społecznych, Wydawnictwo Znak, Kraków 2007.

Śliwerski B., Problemy współczesnej edukacji. Dekonstrukcja polityki oświatowej III RP, Wydawnictwa Akademickie i Profesjonalne, Warszawa 2009.

Śliwerski B., Współczesne teorie i nurty wychowania, Oficyna Wydawnicza „Impuls”, Kraków 2010.

Tatarkiewicz W., Historia filozofii, t. 1, PWN, Warszawa 1978.

Wojciszke B., Psychologia społeczna, Wydawnictwo Scholar, Warszawa 2013.

Wołoszyn S., Źródła do dziejów wychowania i myśli pedagogicznej, wyd. 2, Dom Wydawniczy Strzelec, Kielce 1995.

Znaniecki F., Społeczne role uczonych i historyczne cechy wiedzy, [w:] F. Znaniecki (red.), Społeczne role uczonych, PWN, Warszawa 1984. 